Abstract

\title{
The Benefits of Applying Compost in Agriculture as Aronia Crops Fertilizer ${ }^{\dagger}$
}

\author{
Georgica Pandelea (Voicu) ${ }^{1, *}$, Daniela-Simina Stefan ${ }^{1} \mathbb{D}$, Mirela Florina Calinescu ${ }^{2} \mathbb{D}$, \\ Ivona Cristina Enescu (Mazilu) ${ }^{2,3}$ and Camelia Ungureanu ${ }^{4}$
}

1 Analytical Chemistry and Environmental Engineering Department, Faculty of Applied Chemistry and Materials Science, University POLITEHNICA of Bucharest, 060042 Bucuresti, Romania; simina_stefan_ro@yahoo.com

2 Orchard Technology and Plant Protection Department, Research Institute for Fruit Growing Pitesti, 117450 Arges City, Romania; elacalinescu@yahoo.com (M.F.C.); icmazilu@yahoo.com (I.C.E.)

3 Doctoral School of Plant and Animal Resources Engineering, Horticulture Faculty University of Craiova, 200585 Craiova, Romania

4 General Chemistry Department, Faculty of Applied Chemistry and Materials Science, University POLITEHNICA of Bucharest, 060042 București, Romania; ungureanucamelia@gmail.com

* Correspondence: voicu_georgica@yahoo.com

+ Presented at the 17th International Symposium "Priorities of Chemistry for a Sustainable Development" PRIOCHEM, Bucharest, Romania, 27-29 October 2021.

check for updates

Citation: Pandelea, G.; Stefan, D.-S.; Calinescu, M.F.; Enescu, I.C.;

Ungureanu, C. The Benefits of Applying Compost in Agriculture as Aronia Crops Fertilizer. Chem. Proc. 2022, 7, 8. https://doi.org/ 10.3390/chemproc2022007008

Academic Editors: Mihaela Doni, Florin Oancea, Zina Vuluga and Radu Claudiu Fierăscu

Published: 28 February 2022

Publisher's Note: MDPI stays neutral with regard to jurisdictional claims in published maps and institutional affiliations.

Copyright: (C) 2022 by the authors. Licensee MDPI, Basel, Switzerland. This article is an open access article distributed under the terms and conditions of the Creative Commons Attribution (CC BY) license (https:// creativecommons.org/licenses/by/ $4.0 /)$.
Keywords: chokeberries; composts; vitamin C; anthocyanins; phenolics; leaves minerals

Introduction: This paper presents the preliminary results of a study that aims to emphasize the compost effect, when used as fertilizer, in Aronia melanocarpa crops [1-3]. The study was conducted at the Research Institute for Fruit Growing Pitesti-Maracineni, Arges county, Romania, during the 2019-2020 growing season on Aronia melanocarpa fiveyear-old plants. Materials and methods: Two different origin composts, A (in 30 and $40 \mathrm{t} /$ ha doses) and $\mathrm{M}$ (in 20 and $40 \mathrm{t} / \mathrm{ha}$ doses), were administrated, and the results compared to those of untreated plants. Dry weight (DW), total titrable acidity (TTA), total sugar content (TSC), vitamin C (Vit. C), total phenolics, and total anthocyanins content, as quality indicators, were quantified in berries and $\mathrm{N}, \mathrm{P}, \mathrm{K}, \mathrm{Ca}, \mathrm{Mg}, \mathrm{Zn}, \mathrm{Cu}, \mathrm{Mn}$, and Fe levels were determined in Aronia leaves. Conclusions: As the ANOVA test results showed, in the first experimental year, the influence of compost treatments was focused on berries and less on vegetative organs (leaves). The M-40 type compost significantly increased berries DW, only if compared with A-type compost treatments, and M-20 reduced TPC and A-type fertilizer, significantly decreasing DW (A-30), TTA (A-40), Vit. C (A-40), TAC (A-40) and increasing total sugar content (A-40) in Aronia berries; compost application reduced the foliar content of $\mathrm{Zn}(\mathrm{A}-30), \mathrm{Cu}(\mathrm{M}-40)$, Fe (A-40); by decreasing TPC and TAC, compost fertilization proved a helpful instrument in reducing plant abiotic stress.

Author Contributions: Conceptualization, C.U. and M.F.C.; methodology, M.F.C.; software, I.C.E.; validation, D.-S.S., C.U. and M.F.C.; formal analysis, G.P.; investigation, M.F.C.; G.P. and I.C.E.; resources, M.F.C.; data curation, C.U.; writing-original draft preparation, M.F.C.; D.-S.S. and C.U.; writing-review and editing, M.F.C.; D.-S.S. and C.U; visualization, M.F.C.; G.P.; D.-S.S. and C.U.; supervision, C.U.; project administration, M.F.C. and I.C.E.; funding acquisition, M.F.C. All authors have read and agreed to the published version of the manuscript.

Funding: This research received no external funding.

Institutional Review Board Statement: Not applicable.

Informed Consent Statement: Not applicable.

Conflicts of Interest: The authors declare no conflict of interest. 


\section{References}

1. Aminifard, M.; Aroiee, H.; Azizi, M.; Nemati, H.; Jaafar, H. Effect of compost on antioxidant components and fruit quality of sweet pepper (Capsicum annuum L.). J. Cent. Eur. Agric. 2013, 14, 47-56. [CrossRef]

2. Bedada, W. Compost and Fertilizer-Alternatives or Complementary? Management Feasibility and Long-Term Effects on Soil Fertility in an Ethiopian Village. Ph.D. Thesis, Faculty of Natural Resources and Agricultural Sciences, Swedish University of Agricultural Sciences, Uppsala, Sweden, 2015; p. 123. Available online: http://pub.epsilon.slu.se/12825 (accessed on 15 September 2021).

3. Chrubasik, C.; Li, G.; Chrubasik, S. The clinical effectiveness of chokeberry: A systematic review. Phytother. Res. 2010, 24, 1107-1114. [CrossRef] [PubMed] 